\title{
IMPLEMENTASI RESTORATIVE JUSTICE DALAM PENEGAKAN HUKUM PAJAK
}

\author{
Sarwirini \\ sarwirini.rini@gmail.com \\ Fakultas Hukum Universitas Airlangga
}

\begin{abstract}
In order to prevent the tax evasion, the tax law can be enforced by tax collection, tax assessment and tax investigation. This paper is based on legal research using statute and conceptual approaches. The legal issues of this paper focus on two problems; the philosophical basis and general philosophy of restorative justice in the law enforcement and whether the philosophical and restorative justice principles become a foundation for the tax law enforcement in Indonesia. The result of the paper indicates that the philosophical and the restorative justice principle has become the foundation for regulation and tax enforcement rather than repressive or retributive justice. Persuasive approach focused on tax payers and officers' consensus is the best mechanism for tax evasion, not only related on civil and criminal matters, but also for administrative. The implementation of restorative justice principle will be appropriate if the principle is accompanied by good governance principles.
\end{abstract}

Keywords: tax, restorative justice, law enforcement, persuasive, and concensus.

\begin{abstract}
Abstrak
Dalam rangka menanggulangi pelanggaran hukum di bidang perpajakan, penegakan hukum pajak dilaksanakan melalui upaya penagihan pajak, pemeriksaan pajak, dan penyidikan pajak. Melalui penelitian yuridis normative dengan pendekatan perundang-undangan dan konsep, artikel ini fokus pada dua permasalahan yakni landasan filosofi dan prinsip-prinsip restorative justice dalam penegakan hukum dan mengenai apakah filosofi dan prinsip-prinsip restorative justice tersebut juga menjadi landasan penegakan hukum pajak di Indonesia, melalui upaya penagihan pajak, pemeriksaan pajak, dan juga penyidikan tindak pidana di bidang perpajakan. Permasalahan tersebut diteliti mengingat pelanggaran hukum di bidang perpajakan berakibat kerugian keuangan negara, sementara pajak merupakan kontribusi atau pengalihan kekayaan wajib pajak kepada negara yang digunakan untuk kesejahteraan masyarakat. Hasil penelitian menunjukan bahwa filosofi dan prinsip-prinsip restorative justice secara proporsional melandasi pengaturan dan pelaksanaan penegakan hukum pajak dibandingkan dengan prinsip-prinsip represif atau retributive justice sehingga berimplikasi terhadap peningkatan pendapatan negara dari sektor pajak serta sekaligus tercapainya perlindungan wajib pajak.
\end{abstract}

Kata kunci: pajak, restorative justice, penegakan hukum, persuasif, dan musyawarah dan mufakat. 


\section{Pendahuluan}

Dalam Pasal 23 UUDRI Tahun 1945 diatur bahwa "Pajak dan pungutan lain yang bersifat memaksa untuk keperluan negara diatur dengan undang-undang". Berdasarkan pada landasan konstitusional tersebut, selanjutnya dalam Ketentuan Pasal 1 angka 1 Undang-Undang Nomor 28 Tahun 2007 Tentang Perubahan Ketiga Undang-Undang Nomor 6 Tahun 1983 Tentang Ketentuan Umum Dan Tata Cara Perpajakan (selanjutnya disebut UU KUP) ditentukan bahwa "Pajak adalah kontribusi wajib kepada negara yang terutang oleh orang pribadi atau badan yang bersifat memaksa berdasarkan Undang-Undang, dengan tidak ada imbalan secara langsung dan digunakan untuk keperluan negara bagi sebesar-besarnya kemakmuran rakyat".

Pajak adalah sumber terpenting dalam penerimaan negara dan dipungut berdasarkan ketentuan peraturan perundang-undangan yang berlaku, dan untuk melaksanakannya dikeluarkanlah Keputusan Menteri Keuangan sampai Keputusan Direktorat Jenderal Pajak (selanjutnya disebut Ditjen Pajak) sebagai lembaga pemerintah yang mengemban tugas dan tanggung jawab menghimpun penerimaan dalam negeri dari sektor pajak guna membiayai anggaran penyelenggaraan pemerintah, pelayanan umum dan pembangunan nasional. Ditjen Pajak mempunyai tugas yang sangat berat, karena hampir seluruh penerimaan negara dipikul dari pajak-pajak yang dikelola oleh Ditjen Pajak.

Dalam Tahun 2013, Pendapatan Negara direncanakan Rp1.507,7 T, naik $11 \%$ dari target APBN-P 2012, atau meningkat dua kali lipat dibanding realisasi tahun 2007. Peningkatan pendapatan negara yang signifikan tersebut telah memperbesar kemampuan membangun, memperluas ruang gerak pendanaan bagi berbagai program peningkatan kesejahteraan rakyat, dan meningkatkan kemandirian bangsa. Dalam lima tahun terakhir, peranan penerimaan pajak dalam pendapatan negara meningkat dari $60 \%$ menjadi hampir $70 \%{ }^{1}$ Sejak reformasi perpajakan tahun 1983, dengan beberapa kali perubahan terakhir pada Tahun 2000 (khusus UU KUP diubah terakhir Tahun 2009), sistem pemungutan pajak telah mengalami perubahan mendasar. Perubahan mendasar terkait sistem pemungutan pajak tersebut terjadi yaitu, yang semula dari sistem yang petugas pajaknya aktif melakukan penagihan pajak kepada wajib pajak melalui penerbitan ketetapan pajak (Official Assessment System) menjadi sistem pemungutan pajak yang mendasarkan keaktifan wajib pajak atau penanggung pajak sendiri dalam menentukan, menghitung, dan melaporkankan jumlah pajaknya yang harus dibayar (Self Assessment System).

Berhasil tidaknya implementasi sistem pemungutan pajak self assessment tersebut tentunya sangat bergantung pada pengetahuan dan pemahaman masyarakat, khususnya wajib pajak, terhadap substansi peraturan perundang-undangan pajak yang terkait dengan sistem self assessment tersebut. Setelah 30 (tiga puluh) tahun terjadinya reformasi hukum pajak di Indonesia, peningkatan pemahaman wajib pajak atas sistem self assessment tersebut tentunya diharapkan secara signifikan dapat meningkatkan pendapatan negara yang diperoleh dari sektor pajak.

www.anggaran.depkeu.go.id. 
Dalam hal ini peran masyarakat dalam pemenuhan kewajiban di bidang perpajakan perlu terus ditingkatkan dengan mendorong kesadaran, pemahaman, dan penghayatan bahwa pajak adalah sumber utama pembiayaan negara dan pembangunan nasional serta merupakan salah satu kewajiban dimana setiap anggota masyarakat wajib berperan aktif dalam melaksanakan sendiri kewajiban perpajakannya. Namun dalam kenyataan tidak semua Wajib Pajak menjalankan kewajiban perpajakan sesuai dengan ketentuan perpajakan. Akibatnya Direktur Jenderal Pajak harus menerbitkan ketetapan pajak baik berupa Surat Tagihan Pajak maupun Surat Ketetapan Pajak. Wajib Pajak harus melunasi pajak yang masih harus dibayar sesuai yang tercantum dalam Surat Tagihan Pajak maupun Surat Ketetapan Pajak paling lama satu bulan.

Jika batas waktu tersebut dilampaui, pelaksanaannya bisa dipaksakan berlandaskan pada Undang-Undang Penagihan Pajak Dengan Surat Paksa berdasarkan UU N0. 19 tahun 1997 jo. UU N0.19 Tahun 2000. Kalau wajib pajak atau penanggung pajak mempunyai utang pajak lebih dari seratus juta rupiah (Rp.100.000.000,-) dan mempunyai etika buruk mengalihkan aset kepemilikannya pada pihak lain dengan cara melanggar hukum bisa dikenai penyanderaan badan dan/atau pencekalan. Di samping itu, penagihan pajak ini juga dapat berimplikasi sampai pada penyitaan dan pelelangan barang milik Wajib Pajak atau Penanggung Pajak. Tahapan penagihan pajak tersebut tentunya perlu dilakukan secara persuasif mengingat, sebagaimana pendapat para ahli perpajakan, bahwa sesungguhnya pajak merupakan pengalihan kekayaan rakyat pada negara yang digunakan untuk membiayai pengeluaran negara dan hasilnya ditujukan untuk kesejahteraan rakyat. Dalam rangka mengoptimalkan penerimaan pajak dan mengatasi kenaikan target penerimaan pajak tahun 2013, Direktorat Jenderal Pajak melakukan program ekstensifikasi dan intensifikasi. Program Ekstensifikasi dilakukan dengan upaya sosialisai pajak guna menambah jumlah wajib pajak. Sedangkan Program Intensifikasi dilakukan dengan berbagai cara terhadap wajib pajak yang sudah mendaftarkan diri dan mendapatkan Nomor Pokok Wajib Pajak (NPWP). Menurut Surat Edaran Direktur Jenderal Pajak Nomor : SE06/PJ.9/2001, program intensifikasi yang dilakukan, antara lain, dengan cara meningkatkan kepatuhan Wajib Pajak atau Penangung Pajak yang sudah terdaftar dalam pemenuhan kewajiban perpajakannya serta menggali potensi pajak yang lain melalui upaya pemeriksaan pajak.

Dari pengaturan sistem pemungutan pajak tersebut jelaslah bahwa pajak mempunyai kedudukan yang sangat penting sebagai sumber utama pendapatan negara. Untuk itu karakter pungutan pajak merupakan pungutan yang "memaksa", namun demikian harus dilaksanakan berlandaskan pada ketentuan Undang-Undang. Dengan demikian, jika seseorang atau badan (korporasi) sebagai wajib pajak atau penanggung pajak tidak membayar pajak sesuai dengan peraturan perpajakan yang berlaku, maka sebagai implikasi hukumnya dapat dikenakan sanksi. Bahkan dalam UU KUP, sanksi terhadap pelanggaran hukum pajak (tax evasion) juga dapat dikenakan pada pihak ketiga dan petugas pajak yang dalam melaksanakan tugasnya melanggar ketentuan peraturan perpajakan ataupun ketentuan lain yang terkait (dalam hal ini KUHP dan UU Tindak Pidana Korupsi). 
Sejak reformasi pajak diundangkan pada Tahun 1983, norma pengaturan sanksi atas pelanggaran pajak (baik sanksi administrasi/non penal maupun sanksi pidana/penal) menjadi semakin banyak jenisnya dan juga semakin berat jumlahnya. Namun demikian pelanggaran hukum pajak, baik berupa pelanggaran administrasi maupun pelanggaran terhadap ketentuan pidananya, tampaknya semakin meningkat dan seringkali mengakibatan kerugian keuangan negara yang sangat besar. Kasus yang menyangkut wajib pajak korporasi besar seperti yang dilakukan oleh PT Asian Agri (PT AA) ataupun kasus yang melibatkan petugas pajak Gayus Hutagaol Tambunan (GHT) bahkan berakibat pada kerugian keuangan negara yang sangat besar sampai mencapai trilyunan rupiah.

Meskipun dalam kasus pelanggaran hukum pajak yang terjadi, termasuk dua kasus besar tersebut, telah diputus dengan sanksi pidana dan denda administrasi yang berat namun kasuskasus pelanggaran hukum pajak tampaknya cenderung meningkat dengan modus operandi yang semakin kompleks. Sementara itu dikalangan beberapa ahli hukum pajak dan ahli hukum pidana mempermasalahkan kecenderungan penerapan sanksi pidana yang cenderung meningkat dan semakin berat tanpa dibarengi dengan penurunan jumlah kejahatan di bidang perpajakan. Di lain pihak, harus dingat bahwa sanksi pidana pada hakekatnya bersifat ultimum remedium.

Terkait dengan penjatuhan pidana terhadap kasus penggelapan pajak PT AA, seorang pakar hukum pidana Romli Atmasasmita menyatakan bahwa “ ...apakah politik hukum pidana Indonesia masih menitik beratkan penghukuman (retributif) sebagai satu-satunya solusi atau menitikberatkan pada pemulihan keadaan ekonomi nasional (restoratif) atau keseimbangan antara keadilan retributif dan keadilan restoratif...."2 Sementara itu menurut John Braithwaite, diperlukan suatu studi yang serius supaya konsep restorative justice dapat diterapkan secara efektif dalam penegakan kasus-kasus pelanggaran hukum pajak, baik yang bersifat pelanggaran ketentuan administrasi maupun penal. ${ }^{3}$

Terkait dengan konsep restorative justice, Wright (1991) mengatakan bahwa tujuan utama dari keadilan restoratif adalah pemulihan sedangkan tujuan keduanya adalah ganti rugi. Dengan konsep tersebut dapat diartikan bahwa proses penegakan hukum atau penanggulangan tindakan pidana melalui pendekatan restoratif adalah suatu proses penyelesaian tindak pidana yang bertujuan untuk memulihkan keadaan yang di dalamnya termasuk ganti rugi terhadap korban ( penulis: ataupun bentuk kompensasi atau restitusi lainnya) melalui cara-cara tertentu yang disepakati oleh para pihak yang terlibat. ${ }^{4}$

Prinsip utama penyelesaian tindak pidana melalui pendekatan restoratif merupakan suatu penyelesaian yang bukan hanya sekedar alat untuk mendukung seseorang untuk melakukan kompromi terhadap terciptanya kesepakatan, tetapi pendekatan yang dimaksud harus mampu menembus ruang hati dan pikiran para pihak yang terlibat dalam proses penyelesaian dalam

\footnotetext{
Romli Atmasasmita, “Kejahatan Korporasi”, Kompas, Jakarta, 21 Januari 2013, h. 6.

John Braithwaite, 2002, Restorative justice \& Responsive Regulation, Oxford University Press, New York, h. 40.

4 Rufinus Hotmaulana Hutauruk, Penanggulangan Kejahatan Korporasi melalui Pendekatan Restoratif Suatu Terobosan, Sinar Grafika, Jakarta, 2013, h. 107.
} 
rangka memahami makna dan tujuan dilakukannya suatu pemulihan dan bentuk sanksi yang diterapkan adalah sanksi yang bersifat memulihkan atau mencegah. ${ }^{5}$ Dengan demikian, pendekatan restoratif tersebut sesungguhnya tidak hanya dapat diterapkan dalam perkara perdata saja, tapi juga dalam perkara administrasi dan perkara pidana, sebagaimana dapat terjadi juga dalam perkara di bidang perpajakan. Tulisan ini difokuskan pada 2 (dua) isu hukum berikut ini: (1) Prinsip-prinsip restorative justice dalam penegakan hukum; dan (2) Implementasi prinsipprinsip restorative justice tersebut dalam penegakan hukum pajak di Indonesia, melalui upaya penagihan pajak, pemeriksaan pajak, serta penyidikan tindak pidana di bidang perpajakan. Tipe penelian ini adalah penelitian hukum normatif, yang dilakukan untuk mencari pemecahan atas permasalahan hukum, sehingga hasil penelitian ini dilakukan untuk memberikan preskripsi mengenai apa yang seyogyanya mengenai permasalahan yang diajukan serta dapat diterapkan dalam praktek hukum. Pendekatan yang digunakan dalam penelitian ini adalah pendekatan perundang-undangan (statute approach) dan pendekatan konseptual (conceptual approach).

Pendekatan perundang-undangan dilakukan dengan menelaah semua undang-undang dan dan regulasi yang terkait dengan isu hukum yg ditangani/dibahas. Sedangkan pendekatan konsep digunakan untuk mengkaji kerangka pikir atau kerangka konseptual maupun landasan teoritis sesuai dengan tujuan penelitian ${ }^{6}$ Oleh karena itulah dalam penelitian ini akan dikaji peraturan perundang-undangan, konsep-konsep hukum, teori-terori hokum, prinsip-prinsip hokum, maupun doktrin-doktrin hukum yang terkait dengan permasalahan Restorative justice dalam Penegakan Hukum Pajak di Indonesia.

\section{Prinsip-Prinsip Restorative justice Dalam Penegakan Hukum}

Penegakan Hukum memiliki 3 (tiga) unsur yang harus diperhatikan, yaitu kepastian hukum (rechtszicherkeit), keadilan (gerechtigkeit), dan kemanfaatan hukum (zweckmassigkeit). Hukum tanpa keadilan adalah sia-sia dan hukum tanpa tujuan atau manfaat juga tidak dapat diandalkan. Suatu hukum yang baik adalah hukum yang mampu menampung dan membagi keadilan pada orang-orang yang diaturnya. ${ }^{7}$ Sedangkan menurut John Rawls terdapat 2 (dua) prinsip keadilan, yaitu "first, each person is to have an equal right to the most extensive basic liberty compatible with a similar libery for others; second, social and economic inequalities are to be arranged so that they are both (a) reasonably expected to be everyone's advented and $(b)$ attached a positions and offices open all". ${ }^{8}$

Dari dua pendapat tersebut dapat disimpulkan bahwa aspek keadilan yang dilandaskan dalam rangka menjamin persamaan hak memegang peranan yang sangat penting dalam penegakan hukum. Sedangkan salah satu konsep keadilan yang aktual menjadi bahan kajian hukum saat ini adalah restorative justice, yang berdasarkan Restorative justice consortium pada

\footnotetext{
5 Ibid.

6 Ibid., h. 93.

7 Sudikno Mertokusumo dan A. Pitlo, Bab-Bab Tentang Penemuan Hukum, Citra Aditya Bhakti, Jakarta, 1993, h. 1-6.

8 John Rawls, A Theory of Justice, Harvard University Press, Massasscusetts, USA, 1971, h. 60.
} 
tahun 2006 dimaknai sebagai “....works to resolve conflict and repair harm. It encourages those who have caused harm to acknowledge the impact of what they have done and gives them an opportunity to make reparation. It offers those who have suffered harm the opportunity to have their harmor loss acknowledged and amends made. ${ }^{9}$ Sementara itu, di Indonesia awal munculnya konsep restorative justice secara tegas dan jelas diatur dalam Pasal 1 Butir 14 Undang-Undang No. 11 Tahun 2012 tentang Sistem Peradilan Pidana Anak, yang pengaturannya adalah sebagai berikut:

Keadilan restorative merupakan bentuk penyelesaian konflik dan berusaha untuk menjelaskan kepada pelaku bahwa perilaku tersebut tidak dapat dibenarkan, kemudian pada saat yang sama sebagai langkah untuk mendukung dan menghormati individu. Dengan demikian berarti keadilan restoratif adalah penyelesaian perkara tindak pidana dengan melibatkan pelaku, korban, dan pihak lain yang terkait untuk bersama-sama mencari penyelesaian yang adil dengan menekankan pemulihan kembali pada keadaan semula, dan bukan pembalasan.

Meskipun pengaturan yang tegas dan jelas konsep restorative justice di Indonesia baru pada awal tahun 2012, dengan diundangkannya Undang-Undang tentang Sistem Peradilan Pidana Anak, namun sesungguhnya keberadaan konsep restorative justice sudah berurat akar sejak awal lahirnya bangsa Indonesia. Hal tersebut dapat ditemui melalui bukti-bukti dari prasastiprasasti kuno yang menceritakan adat kebiasaan kuno di Indonesia. Keadaan tersebut bahkan dapat dilihat di dalam karya-karya tulis penulis Barat, seperti pandangan John Braithwaite berikut ini: "Indonesia is a nation with wonderful resources of intracultural restorative justice. Traditions of musyawarah - decision by friendly cooperation and deliberation - traverse the archipelago. Adat law at the same time allows for diversity to the point of local criminal law being wrtten to complement universal national law". ${ }^{10}$

Braithwaite juga mengatakan bahwa: Several years ago in Indonesia I was told of justice rituals in western Sumatra that were jointly conducted by a religious leader and a scholar... the person in the community seen as having the greatest spiritual riches and the person seen as having the greatest richest of learning. My inclination then was to recoil from the elitism of this and insist that many (if not most) citizens have tehe resources (given a little help with training) to facilitatet processes of healing. While I still believe this, I now think it might be a mistake to seek to persuade Asians to democratize their restorative justice practices. ${ }^{11}$

Dari pandangan Braithwaite tersebut dapat digambarkan bahwa konsep restorative justice sesungguhnya bukan merupakan hal yang baru bagi bangsa Indonesia, seperti terlihat dalam pelaksanaan hukum adat di Sumatra Barat. Nilai-nilai musyawarah dan mufakat, yang merupakan nilai-nilai yang ada dalam Sila keempat dari Pancasila, sudah melandasi proses penegakan hukum disana. Bahkan setelah kemerdekaan Negara Republik Indonesia, dan Pancasila ditetapkan sebagai sumber dari segala sumber hukum d Indonesia, setiap produk

9 "Restorative justice Consortium 2006", Varia Peradilan, Tahun XXVII, No. 323, Jakarta, Oktober 2012, h.56.

10 John Braithwaite, op.cit., h. 186 .

11 Ibid., h. 53. 
hukum di Indonesia secara langsung ataupun tidak langsung sesungguhnya sudah dijiwai oleh nilai-nilai yang terkandung dalam konsep restorative justice tersebut.

Dengan berpedoman pada nilai musyawarah dan mufakat tersebut penegakan hukum di Indonesia seharusnya mengedepankan digunakannya penyelesaian sengketa atau konflik hukum dengan cara mengakomodasikan berbagai kepentingan para pihak dalam kedudukan yang sejajar dalam rangka mencarikan suatu solusi yang tepat dan ditrima untuk semua pihak. Mekanisme tersebut nota bene susuai dengan penegakan hukum yang dilakukan dalam masyarakat adat, baik di Indonesia maupun di negara-negara lain, seperti suku-suku bangsa asli di Australia (suku bangsa Aborogin) dan di Selandia Baru (suku bangsa Maori). ${ }^{12}$ Dengan demikian, nilai-nilai yang terkandung dalam restorative justice sesungguhnya sudah merupakan pedoman hidup dan selanjutnya berkembang menjadi pedoman dalam penegakan hukum dalam berbagai bangsa. Bahkan sistem hukum pidana yang berlaku di berbagai negara, baik yang menganut sistem hukum civil law maupun common law, telah menerapkan konsep dasar pendekatan restoratif sebagai bagian dari sistem peradilanan pidana, di samping pendekatan represif dan retributuf lainnya. ${ }^{13}$

Menurut Strang dan Braithwaite, filosofi keadilan restoratif berdasarkan pada prinsipprinsip healing and respectful dialogue, forgiveness, responsibility, apology and making amends. ${ }^{14}$ Dengan berpedoman pada prinsip-prinsip restorative jusyice tersebut, maka dialog/ komunikasi dan hubungan yang saling menghargai harus lebih dahulu dikedepankan dalam proses penegakan hukum daripada proses yang formal. Dengan kata lain lebih baik ditempuh suatu upaya persuasi daripada penjatuhan sanksi, apalagi pada jenis sanksi pidana. Mengingat pada dasarnya saksi pidana itu berkarakter ultimum remedium, kecuali pada kasus-kasus khusus bisa berubah menjadi primum remedium.

Meskipun konsep restorative justice seringkali masih diperdebatkan banyak pihak terkait dengan: 1) restorative processes should be constrained from breaching upper limits on the amount of punishment permissible for a given crime;2) if we are serious about empowering stakeholder, we cannot rule out of order arguments or outcomes that involve punishing offenders, ${ }^{15}$ namun eksistensi restorative justice pada dasarnya sudah lama melandasi nila-nilai kehidupan suku-suku bangsa tradisional di dunia, misalnya pada Suku Maori Di Selandia Baru. ${ }^{16}$ Bahkan di Indonesiapun dapat terlihat dalam suatu kegiatan yang mengedepankan musyawarah dan mufakat, contohnya dalam menyelesaikan permasalahan anak yang berkonflik dengan Hukum. ${ }^{17}$ Namun demikian, nilai-nilai tersebut tampaknya perlu direvitalisasikan kembali

12 Jim Consedine, loc.cit.

13 Rufinus Hotmaulana Hutauruk, op.cit., h.147.

14 Heather Strang dan John Braithwaite, loc.cit.

15 Heather Strang dan John Braithwaite, op. cit., h. 206.

16 Jim Consedine, 1995, Restorative justice, Healing the Effects of Crime, Ploughshares, New Zealand, h.10-13.

17 Nurnaningsih Amriani, "Penanganan Perkara Anak Melalui Konsep Restorative justice”, Varia Peradilan, Oktober 2012, h.26. Lihat juga Suhartatiek, Sri, "Konkretisasi Pendekatan Keadilan Restoratif (Restorative justice) Melalui Diversi Oleh Hakim Anak Di Pengadilan Negeri”, Varia Peradilan, Oktober 2012, 
saat ini. Sementara itu, menurut John Braithwaite, supaya proses penegakan hukum pajak berjalan efektif dan efesien, kegiatan rekonsiliasi (sebagai salah satu nilai dasar restorative justice) seharusnya diatur secara rinci dan diimplementasikan dalam praktek perpajakan. ${ }^{18}$ Terkait dengan hal tersebut, menurut Chairil Anwar Pohan, ketidakberdayaan pemerintah dalam menciptakan iklim yang tidak kondusiff dan kompetitif akan berimbas pada pemberian rasa keadilan dan kepastian hukum pada wajib pajak, dan akan berimplikasi dalam mengoptimalkan investasi dan penerimaan pajak. ${ }^{19}$

Aspek persuasi bahkan telah seringkali diupayakan untuk dipraktikan secara intensif dalam bidang penegakan hukum pajak di Indonesia. Informasi tentang hal tersebut didapatkan dari beberapa kali wawancara secara mendalam dengan pejabat pajak di lokasi observasi penelitian. ${ }^{20}$ Dari observasi tersebut ditemukan bahwa jajaran Direktorat Jenderal Pajak dalam setiap kebijakannya sudah mengupayakan mengadopsi nilai-nilai restoratif justice dalam rangka penegakan hukum pajak, baik dalam upaya penagihan pajak, dan upaya pemeriksaan pajak. Bahkan pada upaya penyidikan tindak pidana di bidang perpajakan, landasan restoratif justice juga digunakan dalam pengaturan penghentian penyidikan tindak pidana di bidang perpajakan yang akan dibahas dalam sub-bab 2 di bawah ini.

\section{Restorative justice Dalam Penagihan Pajak}

Sistem Self Assessment yang dianut setelah reformasi pada Tahun 1984, yang dilandaskan pada KUP, mewajibkan peran serta masyarakat, khususnya wajib pajak untk secara aktif memenuhi kewajiban membayar pajak sesuai dengan ketentuan undang-undang dengan cara menentukan, menghitung, menyetor dan melaporkan sendiri pajaknya. Namun demikian dalam kenyataannya terdapat cukup banyak wajib pajak yang dengan sengaja atau dengan berbagai alasan tidak menjalankan kewajibannya membayar pajak sesuai dengan ketentuan yang berlaku. ${ }^{21}$ Tidak dilunasinya hutang pajak tentunya menjadi beban administrasi tunggakan pajak. Oleh karena itu untuk mencairkan tunggakan pajak yang belum dibayar dilakukanlah tindakan penagihan pajak sesuai dengan ketentuan yang berlaku. Jika terjadi hutang pajak maka akan ditagih melalui Surat ketetapan Pajak kurang bayar. Jika penagihan sudah dilakukan lebih dari satu kali, selanjutnya akan ditindaklanjuti dengan penagihan pajak dengan surat paksa. Dalam hal ini, Surat Tagihan Pajak adalah surat untuk melakukan tagihan pajak dan/atau sanksi perintah membayar utang pajak dan biaya penagihan pajak. ${ }^{22}$

h. $72-73$

18 John Braithwaite, op. cit., h. 227-331,

19 Chairil Anwar Pohan, “Fenomena Keadilan dalam Pengenaan Sanksi Perpajakan”, Indonesia Tax Review, vol. v, ed. 03, 2012, h. 47-48.

20 Wawancara mendalam dengan, antara lain, Dr. Yeskiel Minggus Tiranda, S.H., MH., Kepala Kantor Pelayanan Pajak Pratama Purbalingga, Purbalingga, 28 Oktober 2013.

21 Wirawan B. Ilyas dan Richard Burton, Hukum Pajak: Teori, Analisis, dan Perkembangannya, ed. 6, Penerbit Salemba Empat, Jakarta, 2013, h.103.

22 H. Moeljo Hadi, 2001, Dasar-Dasar Penagihan Pajak Dengan Surat Paksa Oleh Juru Sita Pusat Dan Daerah, Raja Gravindo Persada, Jakarta, h.21. 
Tindakan penagihan tersebut dilakukan berdasarkan ketentuan KUP dan UU No. 19 Tahun 1997 jo. UU No. 19 Tahun 2000 yaitu Undang-Undang tentang Penagihan Pajak dengan Surat Paksa. Undang-Undang tersebut menjadi landasan bagi fiskus atau petugas pajak untuk menagih hutang pajak dari wajib pajak yang tidak mau melunasi hutang pajaknya. Tindakan penagihan pajak berdasarkan Undang-Undang tersebut dilakukan secara persuasif maupun secara represif. Artinya, tindakan penagihan diawali dengan teguran, tetapi bila wajib pajak tidak mengindahkannya baru dilakuan tindakan secara paksa dengan urutan tindakan sebagai berikut: ${ }^{23}$ 1) Surat Teguran; 2) Surat Paksa; 3) Penyitaan; 4) Pelelangan; 5) Hak Mendahulu Pajak; 6) Penagihan Seketika dan sekaligus; 7) Pencegahan, Penyanderaan, dan Gugatan; 8) Angsuran dan Penundaan Pembayaran Pajak; 9) Penghapusan Piutang pajak; 10) Kedaluwarsa

Dari tahapan tersebut bisa digambarkan bahwa mekanisme penagihan pajak lebih mendahulukan prinsip-prinsip restorative justice daripada retributive justice, mengingat visi dan misi Direktorat Jenderal Pajak adalah memasukan uang pajak sebanyak mungkin ke kas negara, karena pajak adalah sumber utama pendapatan negara. Bahkan jika wajib pajak tidak menyetujui tindakan penagihan pajak tersebut atau jumlah pajak yang ditagih tidak disetujui oleh wajib pajak, maka wajib pajak dapat mengajukan keberatan pajak melaui upaya penyelesaian sengketa pajak, yang tahapannya tindakan yang dapat dilakukan wajib pajak adalah sebagai berikut: 1) Upaya hukum keberatan; 2) Upaya hukum banding; 3) Upaya hukum gugatan; 4) Upaya hukum peninjauan kembali; 5) Proses pemeriksaan di pengadilan (Pengadilan Pajak atau Penagadilan TUN). Upaya keberatan merupakan upaya hukum yang diajukan oleh wajib pajak atau penanggung pajak sebagai akibat dari adanya perbedaan penafsiran dan pendirian mengenai ketentuan hukum di bidang perpajakan terhadap suatu kasus tertentu. Perbedaan ini terjadi antara wajib pajak atau penanggung pajak dengan Direktorat Jenderal Pajak dan jajarannya atas penetapan utang pajak untuk jenis Pajak Pusat yang pengelolaannyamenjadi kewenangan Direktorat Jenderal Pajak. Perbedaan persepsi juga dapat terjadi antara wajib pajak dengan Kepala Daerah/Kepala Dinas Pendapatan Daerah dan jajarannya di daerah (baik propinsi maupun kabupaten/kota) atas penetapan besarnya utang pajak untuk Pajak Paerah. Atau dapat terjadi perbedaan penafsiran antara wajib pajak dengan Direktorat Jenderal Bea dan Cukai dan jajarannya atas penetapan bea masuk, cukai, dan sanksi administrasinya. ${ }^{24}$

Baik dalam tahapan tindakan penagihan pajak ataupun penyelesaian sengketa pajak prinsip-prinsip restorative justice lebih dikedepankan daripada penyelesaian melalui jalur pengadilan atau dalam rangka penjatuhan sanksi (retributif). Namun demikian dalam tahapan tindakan-tindakan tersebut tidak menutup kemungkinan justru terjadi "kerjasama" yang merupakan kesepakatan ilegal di antara wajib pajak dan petugas pajak, yang bahkan dapat berimplikasi pada terjadinya Tindak Pidana Korupsi yang dilakukan oleh petugas pajak, seperti terjadi pada kasus Gayus. Di sinilah sesungguhnya perlunya filosofi dan prinsip-

23 Ibid., h.103-136.

24 Y. Sri Pudyatmoko, 2005, Pengadilan Pajak dan Penyelesaian Sengketa Di Bidang Pajak, Gramedia Pustaka Utama, Jakarta, h. 27-28. 
prinsip restorative justice diaplikasikan dalam Kode Etik dan Panduan Pedoman Perilaku Aparatur Pajak dalam menjalankan kewenangannya. Di samping itu, menurut Kepala Kantor Pelayanan Pajak Pratama Purbalingga (Jawa Tengah) dan Rungkut, Surabaya (jawa Timur), ${ }^{25}$ pada dasarnya prinsip-prinsip pemungutan pajak, asas-asas umum pemerintahan yang baik, dan Good governance Principles sebenarnya juga sudah melandasi norma pengaturan dan administarsi perpajakan di Indonesia , khususnya diawali sejak era reformasi hukum pajak pada akhir Tahun 1983.

Jika apatur pajak menyalahgunakan kewenangannya dapat dikenai sanksi administrasi, sanksi perdata, sampai pada sanksi pidana berdasarkan KUP, KUHP, ataupun Undang-Undang Pemberantasan Tindak Pidana Korupsi. Demikian juga jika wajib pajak melakukan pelanggaran hukum pajak, maka terhadap wajib pajak yang bersangkutan dapat dikenai sanksi administrasi, sanksi perdata, maupun sanksi pidana. Terkait dengan sanksi pidana tersebut, sesungguhnya sanksi pidana merupakan ultimum remedium, artinya seharus sanksi pidana diterapkan terakhir jika sanksi-sanksi jenis lain tidak berlaku efektif. Dengan demikian dalam penagihan pajak yang diutamakan sesungguhnya adalah bagaiman cara uang pajak masuk ke kas negara dibandingkan dengan penerapan sanksi (retributif).

\section{Restorative justice Dalam Pemeriksaan Pajak}

Pemeriksaan pajak adalah serangkaian kegiatan menghimpun dan mengolah data, keterangan, dan/atau bukti yang dilaksanakan secara objektif dan profesional berdasarkan suatu standar pemeriksaan untuk menguji kepatuhan pemenuhan kewajiban perpajakan dan/ atau untuk tujuan lain dalam rangka melaksanakan ketentuan peraturan perundang-undangan perpajakan. ${ }^{26}$

Jika dari pemeriksaan pajak ditemukan adanya hutang pajak, maka akan ditindaklanjuti dengan penagihan, sedangkan jika ditemukan adanya bukti permulaan adanya tindak pidana di bidang perpajakan akan ditindaklanjuti dengan penyidikan pajak. Bukti Permulaan adalah keadaan, perbuatan, dan/atau bukti berupa keterangan, tulisan, atau benda yang dapat memberikan petunjuk adanya dugaan kuat bahwa sedang atau telah terjadi suatu tindak pidana di bidang perpajakan yang dilakukan siapa saja yang dapat menimbulkan kerugian pada pendapatan negara. ${ }^{27}$

Tujuan pemeriksaan Pajak adalah serangkaian kegiatan untuk mencari, mengumpulkan dan mengolah data dan/atau keterangan lainnya untuk menguji kepatuhan pemenuhan kewajiban perpajakan dan untuk tujuan lain dalam rangka melaksanakan ketentuan peraturan perundangundangan perpajakan. Dasar hukum pemeriksaan pajak diatur dalam KUP Pasal 1 butir 24 dan Pasal 29 sampai Pasal 31nya serta diatur pula secara rinci dalam Peraturan Menteri Keuangan

25 Wawancara di Kantor Pelayanan Pajak Surabaya pada Tanggal 17 Oktober 2013 dan di Purbalingga pada Tanggal 27 dan 28 Oktober 2013.

26 Diaz Priantara, 2000, Pemeriksaan dan Penyidikan Pajak, Djambatan, Jakarta, h. 26.

27 Ibid., h. 118. 
RI No. 199/PMK.03/2007 tentang Tata Cara Pemeriksaan Pajak.

Pelaksanaan pemeriksaan pajak dilakukan oleh pemeriksa pajak yang telah ditunjuk dan dibuktikan dengan suatu tanda pengenal pemeriksa pajak. Tidak setiap pegawai pajak dapat melakukan pemeriksaan pajak. Mereka yang melakukan pemeriksaan pajak telah dibekali dengan pendidikan berkaitan dengan tata cara pemeriksaan dan pendidikan terkait dengan materi undang-undang pajak yang terkait dengan objek yang akan diperiksa. Sementara itu, terhadap wajib pajak yang akan diperiksa sebaiknya juga mengetahui adanya hak dan kewajiban dalam proses pemeriksaan untuk menghindari adanya kemungkinan terjadi kesalahpahaman antara pemeriksa pajak dan wajib pajak. ${ }^{28}$

Konsep pemeriksaan terhadap wajib pajak berkaitan dengan undang-undang perpajakan tentunya berbeda dengan konsep pemeriksaan menurut auditing atau akuntasi umumnya. Konsep pemeriksaan menurut auditing dan akutansi dalam dunia usaha lazimnya dikenal dalam rangka pemeriksaan keuangan. Obyek yang digunakan dalam pemeriksaannya adalah laporan keuangan perusahaan. Pemeriksaan ini dilakukan oleh pihak yang independen sesuai dengan kualifikasi antara pernyataan yang ditetapkan Standar Profesional Akuntan Publik (SPAP). Sedangkan pemeriksaan pajak menurut KUP dan Peraturan Menteri Keuangan RI adalah suatu hak yang dimiliki oleh fiskus yang bertujuan untuk menguji kepatuhan pemenuhan kewajiban pembayaran pajak dan untuk tujuan laindalam rangka melaksanakan ketentuan perundangundangan pajak. Dengan demikian konsep pemeriksaan pajak toidak selalu berkaitan dengan persoalan kebenaran pembayaran pajak yang telah dilakukan oleh wajib pajak. Persoalan kebenaran administrasi perpajakan juga merupakan salah satu pilar fungsi penegakan hukum pajak yang dilakukan oleh pemerintah (dalam hal ini Direktorat Jenderal Pajak) dalam kerangka sistem self assessment. Sementara itu pilar penegakan hukum pajak yang lain adalah penagihan pajak (tax collection) dan penyidikan pajak (tax investigation). ${ }^{29}$

Dengan demikian jika hasil dari pemeriksaan pajak terdapat pajak yang belum atau kurang dibayar maka akan dilakukan penagihan pajak melalui penerbitan Surat tagihan pajak atau Surat Ketetapan Pajak Kurang bayar. Sementara itu, jika hasil dari pemeriksaan pajak ditemukan adanya bukti permulaan adanya tindak pidana di bidang perpajakan, maka pemeriksaan pajak akan ditindaklanjuti dengan penyidikan pajak. Petugas pemeriksa pajak bisa sama atau berbeda dengan petugas penyidik pajak.

Dalam pelaksanaanya, terkait dengan filosofi dan prinsip-prinsip restorative justice, seharusnya petugas pemeriksa pajak dan wajib pajak melakukan dialog atau komunikasi yang proporsional, transparan, dan hati-hati sehingga hasil musyawarah yang dilakukan menghasilkan kesepakatan yang menguntungkan baik bagi wajib pajak maupun bagi keuangan negara. Jangan sampai terjadi kesepakatan yang hanya menguntungkan bagi wajib pajak dan petugas pajak, sementara keuangan negara dirugikan. Di sinilah pentingnya komitmen petugas pajak untuk menjalankan kewenangannya dalam tugas pemeriksaan pajak sebagai pelayan publik yang

28 Ibid., h. 169.

29 Ibid., h. 170. 
mendasari setiap kegiatan pemeriksaan pajak berdasarkan pada Asas-asas Umum Pemerintahan yang baik dan juga prinsip-prinsip good governance sehingga dapat terhindar dan mencegah terjadinya Kolusi, Korupsi, dan Nepotisme (KKN) di antara wajib pajak dan petugas pajak.

Jika KKN tersebut terjadi, maka baik wajib pajak maupun petugas pajak yang terlibat dapat dikenakan sanksi pidana menurut KUP, KUHP, ataupun Undang-Undang Pemberantasan Tindak Pidana Korupsi. Mengingat menurut Pasal 36 A KUP, petugas pajak pajak yang dalam menjalankan tugas menyalahgunakan wewenangnya dapat dikualifikasi melakukan tindak pidana korupsi atau jika melakukan pemerasan terhadap wajib pajak dapat dikenakan Pasal 368 KUHP.

Memang besarnya kewenangan yang dimiliki aparat pajak, jika tidak disertai dengan adanya pengawasan terhadap mereka, tidak dapat dipungkiri bisa menjadikan wajib pajak sebagai potential victims. Untuk menghindari penyalahgunaan wewenang oleh oknum aparat pajak, dan juga tindakan pemerasan terhadap tersebut, maka wajib pajak sangat memerlukan perlindungan hukum. ${ }^{30}$

Jika prinsip perlindungan wajib pajak didasarkan pada prinsip perlindungan bagi rakyat, maka pada hakekatnya merupakan prinsip pengakuan dan perlindungan terhadap harkat dan martabat manusia yang bersumber pada Pancasila dan prinsip Negara hukum yang berdasarkan Pancasila. ${ }^{31}$ Sedangkan perlindungan hukum bagi rakyat terhadap pemerintah tersebut diarahkan, antara lain, pada usaha-usaha mencegah terjadinya sengketa, menyelesaikan sengketa secara musyawarah, dan penyelesaian sengketa melalui peradilan adalah jalan terakhir. Peradilan hendaklah merupakan ultimum remedium. ${ }^{32}$ Sementara itu, dalam bidang hukum pidana, dalam perkembangannyapun telah muncul upaya-upaya penyelesaian kasus pidana di luar peradilan, semacam upaya Alternative Dispute Resolution, untuk kasus-kasus tertentu, yaitu yang dinamakan mediasi penal. ${ }^{33}$ Dalam hal ini, mediasi penal merupakan penyelesaian sengketa perkara pidana di luar peradilan yang dalam pelaksanaannya menggunakan prinsipprinsip restorative justice. Prinsip-prinsip restorative justice sendiri pada awalnya hanya digunakan sebagai landasan penyelesaian perkara perdata, namun dalam perkembangannya juga digunakan untuk landasan penyelesaian perkara pidana di luar peradilan. ${ }^{34}$ Sementara itu, terdapat pula upaya mediasi di pengadilan.

Mediasi di pengadilan pada awalnya cenderung bersifat sukarela (voluntary), namun dalam perkembangannya kini mengarah pada sifat imperatif atau memaksa (compulsory), yang

\footnotetext{
30 Sarwirini, “Kepatuhan Hukum Dalam Konteks Kebijakan Kriminal di Bidang Perpajakan”, Disertasi, Program Pascasarjana, Universitas Airlangga, Surabaya, 1998, 117.

31 Philipus Mandiri Hadjon, Perlindungan hokum bagi rakyat di Indonesia, sebuah Studi tentang PrinsipPrinsip, Penanganannya oleh Pengadilanb dalam Lingkungan Peradilan Administrasi Negara, Bina Ilmu, 1987, h. 20.

32 Ibid., h.90.

33 Barda Nawawi Arief, 2008, Mediasi Penal-Penyelesaian Perkara Di Luar Pengadilan,Pustaka Magister, Semarang, h. 2-3.

33 John Braithwaite, op.cit.

34 John Braithwaite, op.cit.
} 
landasan filosofinya berlandaskan pada Sila keempat dari Pancasila sebagai dasar negara dan sumber segala sumber hukum di Indonesia. Bahwa mediasi merupakan upaya penyelesaian sengketa atau konflikperkara yang dilakukan secara musyawarah untuk mencapai mufakat (kesepakatan: penulis) yang diliputi semangat kekeluargaan melalui proses perundingan atau perdamaian di antara para pihak yang bersengketa untuk memperoleh kesepakatan bersama. ${ }^{35}$

\section{Restorative justice Dalam Penyidikan Pajak}

Penyidikan tindak pidana di bidang perpajakan adalah serangkaian tindakan yang dilakukan oleh penyidik untuk mencari serta mengumpulkan bukti yang dengan bukti itu membuat terang tindak pidana di bidang perpajakan yang terjadi serta menemukan tersangkanya. Dasar Hukum penyidikan tindak pidana di bidang perpajakan ini adalah KUP dan Peraturan Menteri Keuangan RI No. 130/PMK.03/2009. Tindakan penyidikan ini merupakan tindak lanjut dari proses pemeriksaan bukti permulaan. Mengingat dalam proses pemeriksaan bukti permulaan pada akhirnya akan ditindak lanjuti dengan 3 (tiga) kemungkinan.

Kemungkinan pertama, dilanjutkan dengan tindakan penyidikan apabila ditemukan bukti permulaan yang mengandung adanya unsur tindak pidana perpajakan. Kemungkinan kedua, dilakukan tindakan lain berupa penerbitan Surat Ketetapan Pajak. Penerbitan Surat Ketetapan Pajak dilakukan jika wajib pajak melanggarPasal 13A KUP yaitu wajib pajak karena kealpaannya tidak menyampaikan Surat Pemberitahuan atau menyampaikan Surat Pemberitahuan tetapi isinya tidak benar dan menimbulkan kerugian pada pendapatan negara. Kealpaan wajib pajak dalam hal ini masih merupakan kealpaan yang pertama dilakukan. Konsekuensinya, wajib pajak wajib melunasi kekurangan pembayaran pajaknya ditambah sanksi administrasi $200 \%$ (duaratus persen) dari jumlah pajak yang kurang bayar. Penerbitan Surat Ketetapan Pajak juga dapat dilakukan terhadap wajib pajak badan yang tidak memenuhi kewajibannya memperlihatkan dan atau meminjamkan buku atau catatan dari kegiatan usaha atau pekerjan bebas dari wajib pajak yang bersangkutan.

Kemungkinan ketiga, adalah pembuatan laporan sumir. Pembuatan laporan sumir ini karena wajib pajak tidak ditemukan (dengan catatan, apabila di kemudian hari wajib pajak ditemukan, pemeriksaan bukti permulaan akan dibuka kembali) atau wajib pajak meninggal dunia. Laporan sumir juga bisa dilakukan jika wajib pajak menggunakan Pasal 8 ayat (3) UU KUP, yaitu jika wajib pajak dengan kemauan sendiri mengungkapkan ketidakbenaran perbuatannya disertai pelunasan kekurangan pembayaran pajak ditambah sanksi administrasi denda sebesar $150 \%$ (seratus lima puluh persen) dari jumlah pajak yang kurang bayar. Dengan kata lain sekalipun diketahui ada tindak pidana, terhadap wajib pajak tidak akan dilakukan tindakan penyidikan sepanjang wajib pajak mau mengungkapkan sendiri kesalahannya dan melunasu kewajiban pelunasan pajak beserta sanksinya. Bahkan proses penyidikan tindak pidana di bidang perpajakanpun dapat dihentikan berdasarkan ketentuan Pasal 44A KUP:

35 Rachmadi Usman, Mediasi Di Pengadilan, Dalam Teori dan Praktek, Sinar Grafika, Jakarta, 2012, h. 26-27. 
Pengaturan penyidikan tindak pidana di bidang perpajakan ini merupakan suatu kebijakan dalam rangka "menyelamatkan" keuanganan negara. Mengingat pembuktian dan penyelesaian kasus persidangan tindak pidana di bidang perpajakan memerlukan waktu, tenaga, dan ongkos (cost) yang besar. Sementara sanksi pidana dalam tindak pidana di bidang perpajakan ${ }^{36}$ semakin berat namun seringkali tidak menimbulkan efek jera. Disinilah sesungguhnya telah diterapkan prinsi-prinsip restorative justice dan ultimum remedium, karena lebih mengutamakan pemasukan keuangan negara daripada melanjutkan proses penyidikan yang kemungkinan berakibat dipidananya wajib pajak. Padahal, proses pemidaan terhadap wajib pajak seringkali memerlukan jankawaktu yang lama dalam rangka pengumpulan buktibuktinya. Di lain pihak, tidak semua penegak hukum mengertian dan memahami secara terinci pengaturan dan permasalahan perpajakan yang sangat kompleks, yang memerlukan keahlian yang sangat khusus dalam menemukan solusinya. Juga dengan penghentian penyidikan, uang pajak yang belum dibayar beserta sanksi administrasi sebesar empat kali uang pajak yang belum dibayar dapat secara lebih cepat masuk ke kas negara. Untuk memperoleh penghentian penyidikan tindak pidana di bidang perpajakan, khususnya untuk kepentingan penerimaan negara, wajib pajak harus mengajukan permohonan secara tertulis kepada Menteri Keuangan dengan tembusan kepada kepada Direktur Jenderal Pajak. Surat Permohonan dilampiri dengan pernyataan yang berisi pengakuan bersalah dan kesanggupan melunasi pajak yang belum dibayar. Dalam ketentuan inilah terlihat jelas bahwa hak dan kewajiban wajib pajak dalam membayar atau melunasi kekurangan pajaknya diatur dengan terinci beserta konsekuensi pembayaran sanksi administrasinya. Dalam proses penentuan jumlah hutang pajak yang belum atau kurang bayarpun wajib pajak mempunyai hak untuk mengajukan keberatan untuk mendapat pengurangan, atau pengasuran, atau bahkan penghapusan hutang pajaknya.

Dari kronologis mekanisme penagihan pajak, pemeriksaan pajak, dan penyidikan pajak tersebut di atas terlihat bahwa upaya persuasif yang berlandaskan musyafarah sudah cukup melandasi pengaturan perpajakan di Indonesia, dan senantiasa diupayakan oleh aparat pajak dalam rangka mengumpulkan dan meningkatkan pendapatan negara dari sektor pajak.

\section{Kesimpulan}

Filosofi restorative justice dalam penegakan hukum pada hakekatnya sesuai dengan nilai-nilai yang mendasari Sila Keempat dalam Pancasila, yaitu musyafarah dan mufakat. Secara universal, filosofi restorative justice sudah sejak lama menjadi way of life masyarakat tradisional dari bangsa-bangsa moderen yang ada di dunia saat ini, yang didasarkan pada prinsip-prinsip "healing and respectful dialogue, forgiveness, responsibility, apology and making amends". Dalam penegakan hukum pajak prinsip-prinsip restorative justice tersebut sesungguhnya bisa diaplikasikan secara persuasif dengan harus tetap berpedoman pada norma penegakan hukumnya dalam rangka meningkatkan pendapatan negara. Peraturan perundang-undangan yang terkait

36 Waluyo, Bambang, 1989, Tindak Pidana Perpajakan, Pradnya Paramita, Jakarta, h. 84-85. 
dengan penegakan hukum pajak di Indonesia pada dasarnya sebagian besar sudah berlandaskan pada prinsip-prinsip restorative justice. Namun demikian dalam perkembangannya semakin cenderung mengedepankan cost. Disamping itu, mengingat besarnya wewenang aparat pajak, maka dalam penerapannya berpotensi dimanipulasi melalui kesepakatan atau kerjasama ilegal yang "saling menguntungkan" diantara aparat pajak pajak dan wajib pajak, sehingga dapat berimplikasi uang pajak yang masuk ke kas negara berkurang.

Pentingnya mengaplikasikan prinsip-prinsip restorative justice, baik dalam peraturan perundang-undangan perpajakan maupun dalam implementasinya, untuk mencegah terjadinya pelanggaran administrasi ataupun ketentuan pidana di bidang perpajakan. Implementasi prinsip-prinsip restorative justice oleh aparatur pajak dalam menjalankan kewenangnya dalam penagihan pajak, pemeriksaan pajak dan penyidikan pajak pada hakekatnya juga sekaligus mengaplikasikan prinsip-prinsip pemungutan pajak, prinsip-prinsip umum pemerintahan yang baik, dan prinsip-prinsip good governance, khususnya yang terkait dengan prinsip-prinsip proporsionalitas, transparansi, akuntanbilitas, efektivitas dan kehati-hatian. Prinsip-prinsip restorative justice hendaknya menjadi spirit dalam mengakomodasikan kepentingan untuk mengamankan pendapatan negara yang berasal dari pajak dan juga dalam rangka melindungi hak-hak wajib pajak.

\section{Daftar Bacaan}

\section{Buku}

Amriani, Nurnaningsih, "Penanganan Perkara Anak Melalui Konsep Restorative justice", Varia Peradilan, Oktober 2012.

Arief,BardaNawawi,2008,MediasiPenal-PenyelesaianPerkaraDiLuar Pengadilan,Pustaka Magister, Semarang.

Atmadja, Arifin P. Soeria, 2009, Keuangan Publik dalam Perspektif Hukum, Teori, Kritik, dan Praktek, RajaGrafindo Persada,Jakarta.

Atmasasmita, Romli, “Kejahatan Korporasi”, Kompas, Jakarta, 21 Januari 2013.

Barkoczy, Stephen, 2010, Foundation of Taxation Law, CCH Australia Lt., Australia.

Black, Henry Chambell, 1979, Black's Law Dictionary, fifth ed., St. Paul Minnesota, Massachusetts.

Braithwaite, John, 2002, Restorative justice \& Responsive Regulation, Oxford University Press, New York.

Consedine, Jim, 1995, Restorative justice, Healing the Effects of Crime, Ploughshares, New Zealand.

Dignan, James, 2005, Understanding Victims and Restorative justice, Open University Press, 
New York.

Disintegration: the Control of Tax Evasion in Pakistan, "Journal Law and Society, vol. 16, Number 4, Winter 1989.

Djatmiati, Tatik S., "Pelayanan Publik dan dan Tindak Pidana Korupsi” dalam Philipus Mandiri, et al., 2010, Hukum Administrasi Dan Good Governance, Universitas Trisakti, Jakarta.

Elffers, Henk, 1991, Income Tax Evasion, Theory and Measurement, Kluwer, Deventer, the Netherlands.

Goldsmith, Andrew and Mark Israel, 2000, Criminal Justice in Diverse Communities, The Federation Press, New South Wales, Australia.

Hadi, H. Moeljo, 2001, Dasar-Dasar Penagihan Pajak Dengan Surat Paksa Oleh Juru Sita Pusat Dan Daerah, Raja Gravindo Persada, Jakarta.

Hadjon, Philipus Mandiri, et al., 2010, Hukum Administrasi Dan Good Governance, Universitas Trisakti, Jakarta.

Hadjon, Philipus Mandiri, et al., 2011, Hukum Administrasi Dan Tindak Pidana Korupsi, Gadjah Mada University Press.

Hutauruk, Rufinus Hotmaulana, 2013, Penangulangan Kejahatan Korporasi melalui Pendekatan Restoratif, Suatu Terobosan Hukum, Sinsar Grafika, Jakarta.

Levi, M, dan Mohammad Suddle, "White - Collar Crime, Shamelessness, and

Marzuki, Peter Mahmud, 2005, Penelitian Hukum, cet. 6, Kencana Prenada Media Group, Jakarta.

Morris, Allison and Gabrielle Maxwell, 2003, "Restorative for Adult Offender: the New Zealand Experience", Repositioning Restorative justice, Lode Walgrave (ed.), Wilan Publishing, Oregon, USA.

Packer, Herbert, 1979, The Limits of Criminal Sanction, the Claredon, Oxford.

Priantara, Diaz, 2000, Pemeriksaan Dan Penyidikan Pajak, Djambatan, Jakarta.

Pudyatmoko, Y. Sri, 2005, Pengadilan Pajak dan Penyelesaian Sengketa Di Bidang Pajak, Gramedia Pustaka Utama, Jakarta.

Rock, Paul, 2004, Constructing Victims'Rights, Oxford University Press, New York.

Saidi, Muhammad Djafar, 2008, Hukum Keuangan Negara, Rajawali Press, Jakarta.

Sarwirini, "Kepatuhan Hukum Dalam Konteks Kebijakan Kriminal di Bidang Perpajakan”, Disertasi, Program Doktor, Program Pascasarjana, Universitas Airlangga, Surabaya, 
1998.

--------, "Penegakan Hukum Di Bidang Perpajakan", Makalah Call Paper, Konggres dan Simposium Nasional Masyarakat Hukum Pidana Indonesia (MAHUPIKI), Makasar, 2013.

--------, "Pelanggaran Hukum Pajak yang Berimplikasi Tindak Pidana Korupsi dan Upaya Penegakan Hukumnya", Prosiding Seminar Nasional dan Call for Paper: Korupsi dalam Kepelbagian Interpretasi, Faultas Hukum Universitas Kristen Satya Wacana, Salatiga, 29-29 Januari 2014.

Soekanto, Soerjono, 2002, Penegakan Hukum, ed. Revisi, Cipta Aditya, Jakarta.

Soemitro, Rochmat, Asas Dan Dasar Perpajakan 2, 1998, Refika Aditama, Bandung.

Strang, Heather and John Braithwaite, 2000, Restorative justice, Philosophy to Practice, Dartmouth Publishing, England.

Strang, Heather, 2002, Repair or Revenge, Victims and Restorative justice, Claredon Press, Oxford.

Suhartatiek, Sri, "Konkretisasi Pendekatan Keadilan Restoratif Melalui Diversi Oleh Hakim Anak Di Pengadilan Negeri”, Varia Peradilan, Oktober 2012.

Tella, Maria J.Falcon Y. and Fernando Y. Tella, 2006, Punishment \& Culture: A Right to Punish.

Varma, Kimberly M., and Anthony M. Doob, "Deterring Economics Crimes: The Case of Tax Evasion”, Canadian Journal of Criminology, April 1998.

Waluyo, Bambang, 1989, Tindak Pidana Perpajakan, Pradnya Paramita, Jakarta.

\section{Jurnal}

Canadian Journal of Criminology, April 1998.

Jurnal Indonesian Tax Review, vol. II, ed. 24/2010

Jurnal Indonesian Tax Review, vol. III, ed. 01, 2010

Jurnal Indonesian Tax Review, vol. III, ed. 02, 2010

Jurnal Indonesian Tax Review, vol. III, ed. 03, 2010

Jurnal Indonesian Tax Review, vol. IV, ed. 21, 2011

Jurnal Indonesian Tax Review, vol. V, ed. 03, 2012

Varia Peradilan, Oktober 2012. 

A

abuse 209

alasan pembatalan 314

anak luar kawin 149, 367

arbitrary 17

arbitrase 17,314

arbitration 314

asuransi jiwa 249

B

bagi hasil 113

bank 263

bank agency 263

bank syariah 1

banking 209,221

bankruptcy 61

$\mathrm{C}$

cancellation 314

citizenship 303

civil procedural law 17

civil rights 352

collateral 237

consensus 386

constitutional convention 149

constitutional court 149

constitutional review 167

contract 249

conventional banking 190

court decision 100

credit 221

criteria 39

cybercrime 336

D

debitor 61

debtors. 61

decision 167, 314

dissenting opinion 167

$\mathrm{E}$

electronic transactions system 336

equity 113

ex aequo et bono 100

ex aqequo et bono 100

exception 39

F

filsafat 139 financing 1

G

GCG 190

good faith 249

goverment 336

$\mathrm{H}$

hak asasi manusia 303

hak eksklusif 39

hak keperdataan 149, 367

hak keperdataan 367

health 83

hospital 83

hukum acara perdata 17

human rights 303

I

international agreement 278

investasi 263

investment 263

itikad baik 249

izin 352

J

jaminan 237

justice 367

K

keadilan 149, 367

keagenan bank 263

kepailitan 61

kesehatan 83

kewarganegaraan 303

kontrak 249

kredit 221

kreditor 61

$\mathrm{L}$

law enforcement 386

legal risk 1

legislation 278

license 209

life insurance 249

limitation 39

local autonomy 124

local rules 124 
M

maladministrasi 352

minyak dan gas bumi 113

modernisme 139

mufakat 386

musyawarah 386

$\mathrm{O}$

oil and gas 113

other creditors 61

otonomi daerah 124

$\mathrm{P}$

pajak 386

pancasila 139

paten 39

pelayanan kesehatan 83

pelayanan publik 124

pembiayaan 1

pendapat berbeda 167

penegakan hukum 386

pengujian undang-undang 167

penyalahgunaan 209

peraturan daerah 124

perbankan 209, 221

perbankan konvensional 190 perbankan syariah 190

perizinan 209

perjanjian internasional 278

permissions 352

perolehan kembali 303

persuasif 386

petitum 100

philosophy 139

principles of law 113

prinsip 221

prinsip hukum 113

prinsip pembuktian 17 production sharing 113

proofing principles 17

public interest 39

public service 124

publicity 237

publisitas 237

putusan 314

putusan hakim konstitusi 167

putusan pengadilan 100

$\mathrm{R}$

ratification 278

recovery 303

regulation 336

resi gudang 237

responsibilities 352

restorative justice 386

retribusi, 124

risiko hukum 1

rumah sakit 83

$\mathrm{S}$

sharia banking 190

$\mathrm{T}$

tanggung jawab 352

$\operatorname{tax} 386$

TRIP'S 39

$\mathrm{U}$

ultra petita 100

undang-undang 278

unwritten law 149

W

warehouse receipts 237

wedlock 367 